\title{
Isolated subglossopalatal membrane: a rare entity to encounter
}

\author{
Piyush Kumar, Shiv Narain Kureel
}

Department of Paediatric Surgery, King George's Medical University, Lucknow, Uttar Pradesh, India

\section{Correspondence to} Dr Piyush Kumar, drpiyushkashyapms@gmail.com

Accepted 1 March 2016
CrossMark

\section{To cite: Kumar $P$} Kureel SN. BMJ Case Rep Published online: [please include Day Month Year] doi:10.1136/bcr-2016214642

\section{DESCRIPTION}

Subglossopalatal membrane is a fibrous connection extending from the floor of the mouth to the palate. There are case reports of this condition being associated with other congenital anomalies and syndromes. ${ }^{1}{ }^{2}$ However, isolated subglossopalatal membrane has never been reported in the literature. Earlier, it was believed to be a surgical emergency; however, a recent report has shown that surgical outcome is better if the newborn is stabilised with primary management. ${ }^{3}$ This comprises supplemental oxygen, antibiotics and intravenous fluid followed by surgical excision. ${ }^{3}$

A 2-day-old full-term male neonate presented to the Department of Paediatric Surgery, King George's Medical University, with a membrane detected incidentally by the mother during feeding. The patient did not have any evidence of respiratory distress. On examination, there was a membrane extending from the floor of the mouth to the junction of the soft and hard palate (figures 1 and 2). Lateral extension was from the right molar trigone to the left molar trigone. There was a small rent in the middle of the membrane. Respiratory distress probably did not occur due to this defect. This subglossopalatal membrane was an isolated congenital anomaly in this patient.

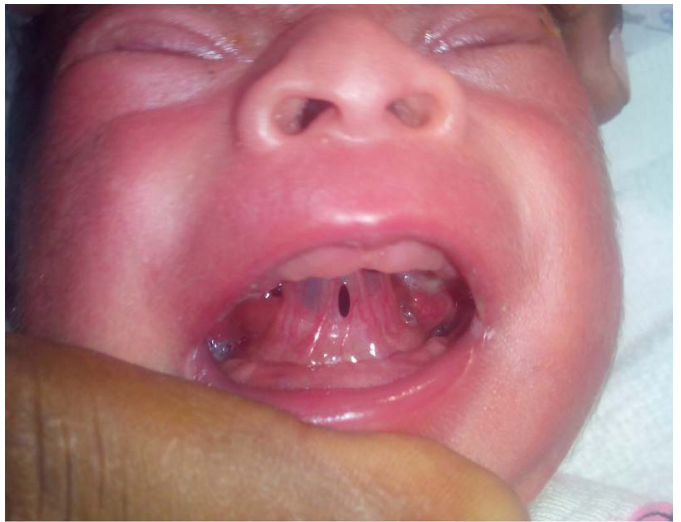

Figure 1 Subglossopalatal membrane.

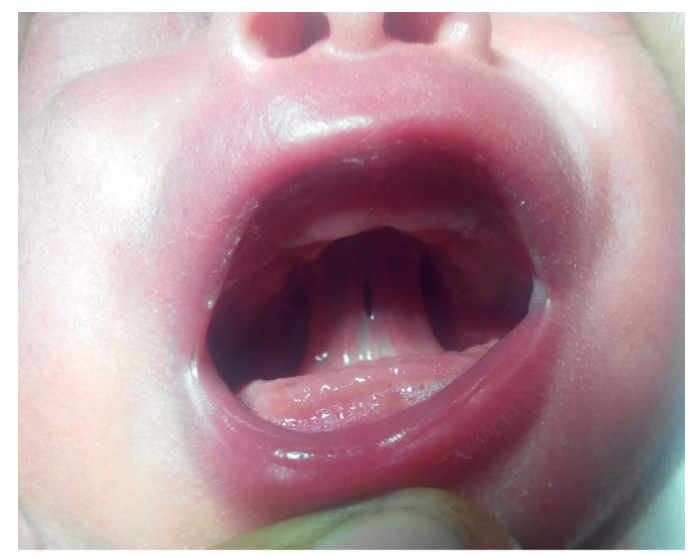

Figure 2 Attachment of subglossopalatal membrane to hard palate.

\section{Learning points}

Presence of subglossopalatal membrane in isolation is an extremely rare anomaly.

- In cases of complete subglossopalatal membrane, it may present as acute respiratory distress in newborns.

- Splitting of the membrane or a natural rent decreases the severity of respiratory distress.

Competing interests None declared.

Patient consent Obtained.

Provenance and peer review Not commissioned; externally peer reviewed.

\section{REFERENCES}

1 Nakajima T, Takahashi M, Tateno S. Subglossopalatal membrane. Plast Reconstr Surg 1979;63:574-6.

2 Zalzal GH, Bratcher GO, Cotton RT. Subglossopalatal membrane. Arch Otolaryngol Head Neck Surg 1986;112:1101-3.

3 Pandey V, Tiwari P, Tapadar J, et al. Subglosso-palatal membrane a rare cause of neonatal respiratory distress. J Indian Assoc Pediatr Surg 2014;19:109-11.

Copyright 2016 BMJ Publishing Group. All rights reserved. For permission to reuse any of this content visit http://group.bmj.com/group/rights-licensing/permissions.

BMJ Case Report Fellows may re-use this article for personal use and teaching without any further permission.

Become a Fellow of BMJ Case Reports today and you can:

- Submit as many cases as you like

- Enjoy fast sympathetic peer review and rapid publication of accepted articles

- Access all the published articles

- Re-use any of the published material for personal use and teaching without further permission

For information on Institutional Fellowships contact consortiasales@bmjgroup.com

Visit casereports.bmj.com for more articles like this and to become a Fellow 